\title{
EFEK MENGIKUTI EKTRAKURIKULER OLAHRAGA DAN TINGKAT KEBUGARAN JASMANI TERHADAP PEMBENTUKAN SELF-ESTEEM SISWA DI SEKOLAH MENENGAH KEJURUAN (SMK)
}

\author{
Wahyu Saputra, M.Pd \\ Dosen STKIP Subang \\ Wahyu_STKIP87@yahoo.co.id
}

\begin{abstract}
The purpose of this study is understanding the effect of sport extracurricular activity and non sport extracurricular activity, and physical fitness level to the student's self-esteem at SMK Cipta Skill Bandung. This study used expost facto method with casual comparative design. Population of this study is all of 150 students in total who join extracurricular in SMK Cipta Skill Bandung, and the sample using accidental sampling technique with 60 students at total. The instrument of this study is self-esteem Inventory (SEI) questionnaire to measure self-esteem score and physical fitness test Indonesia (TKJI) is used to measure physical fitness. Collected data is analized statistically using ANCOVA analizing technique sith significant range $\alpha<0.05$. the result of processed data shows that the score of 1) self-esteem of the students who join sport ectracurycullar is better than non-sport extracurricular. 2) There is no difference of physical fitness to the self-esteem of student who join extracurrycullar. 3) the extracurricular activity and physical fitness makes impact simultaneously to the students self-esteem.
\end{abstract}

Key words : self-esteem, extracurricular, and physical fitness

\section{ABSTRAK}

Tujuan dari penelitian ini adalah untuk memahami pengaruh kegiatan ekstrakurikuler olahraga dan kegiatan ekstrakurikuler non olahraga, dan tingkat kebugaran jasmani terhadap harga diri (self-esteem) siswa SMK CIPTA SKILL Bandung. Metode yang digunakan dalam penelitian ini adalah metode ex post facto dengan desain Causal Comparative. Populasi penelitian adalah semua siswa yang mengikuti ekstrakurikuler di SMK CIPTA SKILL Bandung yang berjumlah 150 siswa, dengan sampel menggunakan teknik Accidental Sampling yang berjumlah 60 orang. Instrumen penelitian yang digunakan adalah angket Self-Esteem Inventori (SEI) untuk mengukur skor self-esteem, tes kebugaran jasmani indonesia (TKJI) digunakan untuk mengukur kebugaran jasmani. Data yang terkumpul dianalisis secara statistika menggunakan teknik analisis ANCOVA dengan taraf signifikansi $\alpha<0.05$. Hasil pengolahan data menunjukkan bahwa nilai 1). Self-esteem siswa yang mengikuti program ekstrakurikuler olahraga lebih baik daripada ekstrakurikuler non olahraga. 2). Tidak ada pengaruh perbedaan kebugaran jasmani terhadap self-esteem siswa yang mengikuti ekstrakurikuler. 3). Kegiatan ekstrakurikuler dan kebugaran jasmani secara simultan berpengaruh terhadap self-esteem siswa..

Kata kunci : Self-esteem, Ektrakurikuler dan Kebugaran Jasmani 


\section{A. Pendahuluan}

Kemajuan

zaman

memunculkan banyak masalah yang dihadapi manusia setiap harinya. Berbagai macam peralatan yang canggih sangat berdampak pada kehidupan manusia, baik dampak positif maupun dampak negatif. Pada dampak negatif misalnya manusia cenderung malas bergerak sehingga energi yang dikeluarkan sangat sedikit. Jika aktivitas dilakukan sangat sedikit dapat dipastikan bahwa dia akan kekurangan gerak atau "hipokinetic". Jika itu terjadi maka kebugaran jasmani akan menurun pula.

Sebagaimana dikemukakan Beltasar Tarigan (2009:2) “...dampak negatif akibat kurangnya gerak atau aktivitas jasmani sehari-hari, menyebabkan terjadinya penyakit kurang gerak yang disebut dengan hipokinesia". Hal ini tentunya sangat berpengaruh terhadap kehidupan dan keseharian kita. Era globalisasi memberikan dampak positif dan negatif bagi kehidupan manusia.
Dampak positif yang dapat dirasakan antara lain keleluasaan mengakses informasi secara cepat dari segala penjuru dunia, tanpa harus pergi ke lokasi kejadian, dan juga dapat mengetahui perkembangan yang terjadi di seluruh dunia. Namun demikian, dibalik dampak positif globalisasi, ada pula dampak negatifnya, antara lain karena terlalu terbukanya informasi yang dapat diperoleh, mengakibatkan penerima informasi tanpa filter yang kuat, hingga sulit menentukan mana informasi yang baik dan buruk.

Sebuah fakta yang menggambarkan tentang kondisi yang cukup memprihatinkan dari remaja yaitu, banyak dijumpai generasi muda yang tidak memanfaatkan waktu yang dimiliki dan cenderung melakukan aktifitas berupa kesenangan seperti jalanjalan yang tidak bermanfaat. Salah satu stasiun televisi swasta yang ada di negeri ini menyoroti terkait kecanduan game on line bagi para anak-anak. Penelitian Andriani 'et al' (2010:7) yang melihat gambaran 
pemilihan game online pada anak menemukan bahwa $82,9 \%$ anak memilih game online bertema kekerasan dan 76,5\% anak menghabiskan waktu 1-2 jam untuk bermain game dalam sehari. Diperkuat oleh Megi Deviandri (2012:2) dalam jurnal penelitiannya menerangkan bahwa : “...dampak game online bagi prilaku siswa sangat besar pengaruhnya karena akan mengurangi mereka dalam bersosialisasi dan berinteraksi dengan masyarakat". Sehingga disimpulkan bahwa kecanduan game online sangat tidak baik terhadap siswa karena akan mengubah dirinya lebih cenderung pendiam, cuek dan egois, dan bisa memicu perasaaan agresif pada anak serta kurangnya interaksi terhadap lingkungan masyarakat. Sehingga peluang waktu yang dimiliki remaja tidak dimanfaatkan untuk aktifitas yang berguna, hal ini dikarenakan salah satunya adalah pemahaman konsep diri (selfesteem) yang kurang.

Semua fenomena yang digambarkan di atas memerlukan penanganan yang sangat serius dalam pendidikan. Sebagaimana dijelaskan oleh Mulyana (2013:3) bahwa " kecenderungan perilaku kekerasan atau perilaku negatif tersebut dapat dianggap sebagai pertanda krisis moral.

Sekolah sebagai salah satu institusi pendidikan formal melakukan berbagai aktivitas dalam rangka mencapai tujuan pendidikan, yaitu meningkatkan kualitas sumber daya manusia, melalui aktivitas belajar-mengajar formal dan berbagai kegiatan yang menunjang pengembangan bakat dan minat para siswa. Salah satu kegiatan yang menunjang pengembangan bakat dan minat para siswa dalam pemanfaatan waktu luang adalah kegiatan ekstrakurikuler. Sesuai penjelasan Surat Keputusan Direktur Jenderal Pendidikan Dasar dan Menengah (SK Dirjen Dikdasmen) Nomor : 226/C/Kep/o/1992 bahwa :

Ekstrakurikuler adalah kegiatan di luar jam pelajaran biasa dan pada waktu libur sekolah, yang dilakukan, baik di sekolah ataupun diluar sekolah, dengan tujuan untuk memperdalam dan memperluas pengetahuan siswa, mengenal hubungan antara berbagai 
pelajaran, menyalurkan bakat dan minat, serta melengkapi upaya pembinaan manusia seutuhnya.

Kegiatan ekstrakurikuler secara garis besar ekstrakurikuler olahraga dan ekstrakurikuler bukan olahraga. Kegiatan-kegiatan yang termasuk ekstrakurikuler olahraga antara lain : ekstrakurikuler olahraga permainan (bola basket, futsal, sepakbola, dan bola voli), dan olahraga beladiri (pencak silat, karate, dan taekwondo). Kegiatankegiatan yang termasuk ekstrakurikuler bukan olahraga antara lain : ekstrakurikuler tari ( tari tradisional, modern dance, dan cheerleader), ekstrakurikuler teater, ekstrakurikuler pramuka, pecnta alam, dan paskibra.

Kegiatan ekstrakurikuler ini memiliki fungsi sebagai sarana bagi para siswa untuk menyalurkan energi, kreativitas, dan pikirannya dalam berbagai kegiatan yang bermanfaat. Keikutsertaan siswa dalam kegiatan ekstrakurikuler diharapkan dapat mengembangkan fisik, mental, dan emosional siswa secara optimal. Ketika bakat, kreativitas, kemampuan, dan keahlian seseorang berkembang menjadi lebih baik, dia akan lebih menghargai dirinya, akan memiliki penilaian yang positif terhadap dirinya dan mempunyai selfesteem (harga diri) yang positif. Sebagaimana penjelasan Rusli Lutan $(2003 ; 8)$ mengemukakan "self-esteem bagi seseorang ibarat fondasi sebuah bangunan rumah. Self-esteem merupakan sebuah struktur penting bagi perkembangan kemampuan yang lainnya.

Di atas self-esteemlah akan terbangun prestasi." Bila selfesteem dan penilaian diri rendah maka apapun yang kita bangun di atasnya niscaya akan mudah retak. Itulah sebabnya self-esteem harus dibangun sekokoh mungkin agar kita dapat mencapai kualitas hidup yang lebih baik.

Harga diri (self esteem) adalah suatu istilah psikologi yang merefleksikan evaluasi menyeluruh seseorang terhadap nilai dirinya. Harga diri (self esteem) meliputi kepercayaan diri dan emosi seperti kemenangan, putus asa, kebanggaan, dan rasa malu. Sebagaimana dikemukakan oleh Coopersmith $\quad(1967: 5)^{\prime \prime}$...it 
espresses an attitude of approval or disapproval, and indicates the extent to which the individual believes himself to be capable, significant, successful, and worthy“. Pertumbuhan fisik dan perkembangan sosial-psikologis di masa remaja pada dasarnya merupakan kelanjutan, yang dapat diartikan penyempurnaan dari proses pertumbuhan dan perkembangan dari proses sebelumnya. Banyak sekali perilaku negatif yang ditimbulkan akibat self-esteem yang rendah seperti yang dijelaskan oleh Coopersmith (dalam Bridges, 2007:13) mengemukakan bahwa :

Low self-esteem contributes to higher suicide rates, depression, teen pregnancy and other health related problems especially during critical adolescent years. Teenagers face so many mental, social and emotional issues in society today; and as physical educators we have the opportunity to help them cope with their changing life. Teenagers need to feel good about themselves; this will contribute toward the confidence to help live a healthy and safe life. Without a strong selfesteem, teenagers may head down the wrong path in life.

Remaja menghadapi banyak sekali masalah mental, sosial, dan emosionalnya dalam kehidupan bermasyarakat saat ini. Remaja butuh merasa nyaman terhadap diri mereka sendiri. Hal ini akan berkontribusi terhadap rasa percaya diri yang akan membantu mereka hidup dalam situasi kehidupan yang sehat dan aman. Tanpa self-esteem yang kuat, remaja dapat memilih jalur kehidupan yang salah. Self-esteem merupakan bagian yang juga sangat berguna untuk menunjang kehidupan individu agar lebih produktif.

Dengan dasar tersebut, peneliti ingin melakukan penelitian kembali untuk menguatkan pengaruh ekstrakurikuler yang berkaitan dengan tingkat kebugaran jasmani dalam pembentukan self-esteem. Dari uraian diatas, maka penelitian ini dilakukan untuk mengetahui : (1). Apakah ekstrakurikuler berpengaruh terhadap self-esteem siswa. (2). Apakah kebugaran 
jasmani berpengaruh terhadap self- esteem siswa. (3). Apakah ekstrakurikuler dan kebugaran jasmani secara simultan berpengaruh terhadap self-esteem siswa.

\section{B. Landasan Teori}

1. Kegiatan Ekstrakurikuler

a. Pengertian Ekstrakurikuler

Kegiatan ekstrakurikuler merupakan kegiatan pengayaan dan perbaikan yang berkaitan dengan program kokurikuler dan intrakurikuler. Kegiatan ini dapat dijadikan sebagai wadah bagi siswa yang memiliki minat mengikuti kegiatan tersebut. Melalui bimbingan dan pelatihan guru, kegiatan ekstrakurikuler dapat membentuk sikap positif terhadap kegiatan yang diikuti oleh para siswa. Menurut Rusli Lutan (1986:72) menjelaskan bahwa Program ekstrakurikuler merupakan bagian internal dari proses belajar yang menekankan pada pemenuhan kebutuhan anak didik.

Antara kegiatan intrakurikuler dan ekstrakurikuler sesungguhnya tidak dapat dipisahkan, bahkan kegiatan ekstrakurikuler perpanjangan pelengkap atau penguat.

Surat Keputusan Direktur Jenderal Pendidikan Dasar dan Menengah (SK Dirjen Dikdasmen) Nomor : $\quad 226 / \mathrm{C} / \mathrm{Kep} / 0 / 1992$ menyatakan bahwa Ekstrakurikuler adalah kegiatan diluar jam pelajaran biasa dan pada waktu libur sekolah, yang dilakukan, baik di sekolah ataupun diluar sekolah, dengan tujuan untuk memperdalam dan memperluas pengetahuan siswa, mengenal hubungan antara berbagai pelajaran, menyalurkan bakat dan minat, serta melengkapi upaya pembinaan manusia seutuhnya.

b. Tujuan dan Peranan Kegiatan Ekstrakurikuler

Dalam setiap kegiatan yang dilakukan, pasti tidak lepas dari aspek tujuan. Oleh karena suatu kegiatan yang diakukan tanpa jelas tujuannya, maka kegiatan itu akan sia-sia. Begitu pula dengan kegiatan ekstrakurikuler tertentu memiliki tujuan tertentu. 


\begin{tabular}{|c|c|}
\hline Narmoatmojo & antara hubungan satu pelajaran \\
\hline mengatakan bahwa kegiatan & dengan pelajaran lainnya. \\
\hline ekstrakurikuler memiliki tujuan agar & c. Olahraga dan Pendidikan \\
\hline siswa dapat memperdalam dan & Karakter \\
\hline memperluas pengetahuan, & Karakter tidak datang dengan \\
\hline mengenal hubungan antar & sendirinya, tetapi diajarkan dalam \\
\hline berbagai mata pelajaran, & program pendidikan jasmani dan \\
\hline $\begin{array}{l}\text { menyalurkan bakat dan minat, serta } \\
\text { melengkapi upaya pembinaan } \\
\text { manusia seutuhnya dalam arti ; } \\
\text { (1)Beriman dan bertaqwa terhadap }\end{array}$ & $\begin{array}{l}\text { olahraga, Pengajaran alasan- } \\
\text { moral dan nilai-nilai olahraga itu } \\
\text { melibatkan penggunaan strategi } \\
\text { tertentu yang sistematis. Telah }\end{array}$ \\
\hline $\begin{array}{l}\text { Tuhan Yang Maha Esa, (2) Berbudi } \\
\text { pekerti luhur, (3) Memiliki } \\
\text { pengetahuan dan keterampilan, (4) }\end{array}$ & $\begin{array}{l}\text { menjadi keyakinan umum bahwa } \\
\text { aktivitas olahraga syarat dengan } \\
\text { nilai -nilai karakter seperti }\end{array}$ \\
\hline $\begin{array}{l}\text { Sehat jasmani dan rohani, (5) } \\
\text { Berkepribadian yang mantap dan }\end{array}$ & $\begin{array}{l}\text { kejujuran, sportivitas, disiplin, dan } \\
\text { kepemimpinan. Sebagaimana }\end{array}$ \\
\hline $\begin{array}{l}\text { mandiri, dan (6) Memiliki rasa } \\
\text { tanggung jawab kemasyarakatan }\end{array}$ & $\begin{array}{l}\text { dikemukakan oleh Mulyana } \\
(2013: 65) \text { bahwa " dalam olahraga, }\end{array}$ \\
\hline Tujuan pelaksanaan & proses pembentukan \\
\hline ekstrakurikuler & terkait dengan empat kebajikan \\
\hline menurut Direktorat Pendidikan & yaitu; compassion, fairne \\
\hline $\begin{array}{l}\text { Menengah Kejuruan (Suryobroto, } \\
1997: 272 \text { ) sebagai berikut ; (1) }\end{array}$ & $\begin{array}{l}\text { sportsmanship, dan integrity. } \\
\text { Bukan hanya guru pendidikan }\end{array}$ \\
\hline $\begin{array}{l}\text { Kegiatan ekstrakurikuler harus } \\
\text { meningkatkan kemampuan siswa } \\
\text { dari aspek kognitif, afektif dan }\end{array}$ & $\begin{array}{l}\text { jasmani yang menyatakan bahwa } \\
\text { berpartisipasi dalam aktivitas } \\
\text { jasmani }\end{array}$ \\
\hline $\begin{array}{l}\text { psikomotor, (2) Mengembangkan } \\
\text { bakat dan minat siswa dalam upaya }\end{array}$ & $\begin{array}{l}\text { perkembangan karakter } \\
\text { perilaku positif. }\end{array}$ \\
\hline pembinaan & (Gould, \\
\hline $\begin{array}{l}\text { pembinaan manusia seutuhnya } \\
\text { yang positif, (3) Dapat mengetahui, } \\
\text { mengenal serta membedakan }\end{array}$ & $\begin{array}{l}\text { 2003:533), seorang ahli di bidang } \\
\text { perkembangan remaja, }\end{array}$ \\
\hline
\end{tabular}


memberikan contoh, kegiatan ekstrakurikuler olahraga sangat potensial untuk mengarahkan anak memiliki perilaku positif, dengan beberapa alasan. Pertama, olahraga secara intrinsik memotivasi remaja.

Kedua, melibatkan upaya yang terus-menerus untuk berpartisipasi ke arah tujuan yang diinginkan. Ketiga, olahraga membutuhkan seperangkat pengalaman, membuat penyesuaian, dan belajar untuk mengatasi masalah.

2. Kebugaran Jasmani Kebugaran

jasmani merupakan unsur yang sangat penting yang harus dimiliki seseorang untuk bisa melakukan aktivitas dengan baik. Kebugaran jasmani adalah derajat sehat dinamis seseorang yang menjadi kemampuan jasmani dasar untuk dapat melaksanakan tugas yang harus dilaksanakan (Giriwijoyo, 2012: 17).

Oleh karena itu diperlukan pembinaan dan pemeliharaan kebugaran jasmani seseorang. Untuk keberhasilan pelaksanaan tugas ini perlu adanya kesesuaian antara syarat yang harus dipenuhi oleh si pelaksana yaitu yang bersifat anatomis dan fisiologis terhadap macam dan intensitas tugas fisik yang harus dilaksanakan.

Oleh karena itu untuk mengetahui tingkat kebugaran jasmani seseorang sebaiknya melalui pengukuran terhadap unsur atau komponen kebugaran jasmani. Kebugaran jasmani mempunyai komponenkomponen yang harus dikembangkan sehingga dapat tercapai secara menyeluruh.

Menurut Nurhasan (2007: 9899) beberapa komponen kebugaran jasmani sebagai berikut; 1). Kekuatan (strenght), 2). Daya (power), 3). Kecepatan (speed), 4). Kelentukan (flexibility), 5).Daya tahan otot (muscular endurance), 6). Daya tahan umum (circulorespiration endurance).

3. Self-Esteem

a. Self-Esteem (Harga Diri)

Harga diri merupakan salah satu konsep sentral dalam kajian psikologi. Terutama pada remaja, 
harga diri sering kali dikaitkan dengan berbagai tingkah laku khas remaja seperti tawuran, penyalahgunaan obat-obatan, pacaran, sampai prestasi olahraga. Coopersmith (1967:37) "A second factor contributing to our selfesteem is our history of successes and the status and position we hold in the world." Pernyataan ini menjelaskan bahwa salah satu faktor yang berkontribusi dalam pembentukan self-esteem yaitu pengalaman sukses, status dilingkungan sosialnya.

Coopersmith

(Gilmore, 1974:42) mengemukakan bahwa : "Self-esteem is a self evaluation of worthiness which is expressed in the attitudes the person holds toward himself". Pendapat ini menjelaskan bahwa penghargaan diri merupakan penilaian individu terhadap kehormatan dirinya yang diekspresikan melalui sikap terhadap dirinya. Dapat diartikan bahwa harga diri menggambarkan sejauhmana individu tersebut menilai dirinya sebagai orang yang memiliki kemampuan, keberartian, berharga, dan kompeten. b. Hubungan antara Self-esteem dan aktivitas fisik

Self-esteem sering dianggap sebagai tujuan penting pendidikan. Secara umum sering dianggap sebagai suatu indikator penyesuaian mental dan sosial, sebagai gambaran kesejahteraan total dan kepuasan dalam kehidupan. Lebih lanjut, dapat dianggap sebagai konsekuensi yang perlu dikembangkan untuk dapat memperkuat motivasi (Harter, 1987; dalam Auweele, 1999:41).

Olahraga ekstrakurikuler memiliki potensi untuk mengembangkan self-esteem dengan cara menanamkan nilainilai perkembangan sesuai minat dan bakat siswa. Karena harga diri (self-esteem) sangat penting agar menjadi manusia yang bernilai.

Biddle dan Mutrie (2007; dalam Lane, 2008:176) menyimpulkan bahwa ada dua pendekatan utama dalam upaya memahami hubungan aktivitas jasmani dan self- esteem : pendekatan pertama disebut 
"pendekatan motivasional" atau dapat juga disebut "personal development

hypothesis".

Pendekatan menempatkan selfesteem sebagai faktor yang menentukan keterlibatkan seseorang di dalam aktivitas olahraga, yang pada waktu bersamaan juga akan menumbuhkan harga diri orang tersebut.

\section{Metode Penelitian}

Penelitian adalah salah satu cara dalam mencari suatu kebenaran melalui cara-cara ilmiah atau metode ilmiah. Metode ilmiah itu, berarti kegiatan penelitian yang didasarkan pada ciri-ciri keilmuan.

Sugiyono

menyatakan ciri-ciri keilmuan sebagai berikut, yaitu rasional, empiris, dan sistematis. Sistematis artinya, proses yang digunakan dalam penelitian itu menggunakan langkah - langkah tertentu yang bersifat logis.

Sehubungan dengan masalah yang diutarakan dalam penelitian ini, penulis mengunakan metode ex post facto. Dalam hal ini
Kerlinger

(1964:360) mendefinisikan metode penelitian ex post facto sebagai The research in which the independent variabel or variabel have already occurred and in which the researchers starts with the observations of a dependent variabel or variabels in retrospect for their possible relations to, and effects on, the dependent variabel or variabels.

Dapat disimpulkan bahwa ex post facto adalah suatu metode penelitian yang di dalamnya variabel bebas telah terjadi atau telah dilaksanakan (tanpa ada perlakuan), dan peneliti memulai dengan mengobservasi hubungan yang terlihat antara variabel bebas terhadap variabel terikat. Lebih lanjut, Sugiyono

(1999:7) mengemukakan bahwa "Penelitian ex post facto adalah suatu penelitian yang dilakukan untuk meneliti peristiwa yang telah terjadi dan kemudian melihat ke belakang untuk mengetahui faktor-faktor yang dapat menimbulkan kejadian tersebut." 
Ciri utama dalam penelitian ex post facto adalah tidak adanya perlakuan yang diberikan oleh peneliti atau dengan kata lain perlakuannya sudah dilakukan tanpa ada control dari peneliti.

Hal ini seperti dijelaskan oleh Nasir (1999:73) sebagai berikut: "sifat penelitian ex post facto yaitu tidak ada kontrol terhadap variabel. Variabel dilihat sebagaimana adanya." Tujuan penelitian ex post facto adalah melihat akibat dari suatu fenomena dan menguji hubungan sebab akibat dari datadata setelah semua kejadian yang dikumpulkan telah selesai berlangsung.

Metode penelitian ex post facto disebut juga dengan istilah metode Causal Comparative atau metode yang mengamati suatu masalah secara mendalam dengan cara membandingkan dua situasi kelompok yang berbeda.

Sesuai dengan penjelasan Adang Suherman (2002:11) menyatakan bahwa "Penelitian kausal komparatif berupaya untuk mengetahui penyebab atau akibat dari suatu perbedaan yang sudah terlebih dahulu muncul diantara dua atau beberapa kelompok individu."

Dapat disimpulkan bahwa metode causal comparative berdasarkan pada aturan dan suatu perjanjian dan perbedaan paham dalam suatu keadaan, yang menyebabkan efek yang diamati.

\section{Pembahasan}

1. Ekstrakurikuler berpengaruh terhadap self-esteem siswa Penulis mencoba menganalisa dari hasil tes tingkat Self-esteem antara yang mengikuti program ekstrakurikuler olahraga dengan ekstrakurikuler non olahraga, ternyata dari kedua program tersebut rata-rata mempunyai pengaruh positif terhadap Self-esteem, namun yang lebih baik dan lebih besar pengaruhnya adalah kelompok pada program ekstrakurikuler olahraga. Pada program ekstrakurikuler olahraga diharapkan siswa dapat meningkatkan self-esteem dengan melakukan aktivitas fisik yang 
terdapat nilai-nilai keolahragaan yang dapat mengembangkan karakter sehingga terbentuk selfesteem kuat.

Sesuai dengan penjelasan Mulyana (2013:66) menyatakan bahwa " olahraga mendorong penguasaan nilai-nilai yang lama melekat seperti kerja sama, fair play, dan menjadi seorang gentleman".

Terjadi perbedaan selfesteem siswa yang mengikuti ekstrakutrikuler olahraga dan ekstrakurikuler non olahraga disebabkan karena kegiatan ekstrakurikuler olahraga menanamkan nilai-nilai keolahragaan yang membangun karakter siswa salah satunya adalah self-esteem.

Hal ini sesuai dengan pernyataan yang diungkapkan oleh Rusdiani (2012:63) menyatakan bahwa : "Tujuan pendidikan olahraga adalah memberikan latihan untuk pembentukan pengetahuan, sikap atau watak, kepribadian serta kesegaran jasmani yang penting bagi kita".
Dengan nilai-nilai yang terdapat dalam olahraga, hal tersebut akan menumbuhkan perasaan percaya diri sendiri karena siswa merasakan keberhasilan dalam pengalaman gerak yang dilakukan dalam aktivitas ekstrakurikuler olahraga. Rasa percaya diri terhadap kemampuan yang dimiliki akan menjadikan siswa merasa memiliki harga diri dalam setiap aktivitas jasmani yang dijalaninya. Sesuai dengan Budimansyah (2011:115) menyatakan bahwa : "Karakter secara koheren memancar dari hasil olah pikir, olah hati, olah rasa, dan karsa, serta olahraga yang mengandung nilai, kemampuan, kapasitas moral, dan ketegaran dalam menghadapi kesulitan dan tantangan."

Ekstrakurikuler olahraga sebagai alat pendidikan memiliki norma-norma dan nilai yang sesuai dengan karakter setiap cabang olahraga yang dipilih menjadi kegiatannya. Seperti diketahui bahwa kegiatan ekstrakurikuler olahraga adalah gerak manusia, dan melalui aktivitas gerak itu 
manusia menyatakan dan mengembangkan dirinya.

Dengan penjelasan di atas jelaslah bahwa ektrakurikuler olahraga lebih baik dari pada ekstrakurikuler non olahraga dalam pembentukan self-esteem siswa. Diketahui nilai t-hitung untuk selfesteem adalah 11.243 dengan probabilitas Sig. (2-tailed) adalah 0.000. Karena probabilitas Sig. (2tailed) $\quad 0,000<0,05$ maka $\mathrm{HO}$ Ditolak. Artinya Self-esteem siswa yang mengikuti ekstrakurikuler olahraga lebih baik daripada siswa yang mengikuti ekstrakurikuler non olahraga.

2. Kebugaran jasmani berpengaruh terhadap self-esteem siswa

$$
\text { Kebugaran jasmani dalam }
$$

arti sempit merupakan satu aspek dari kesegaran keseluruhan manusia. Dengan melakukan aktivitas fisik dengan mengikuti ekstrakurikuler secara teratur dan terarah melalui program yang terencana, maka aktivitas fisik akan mempunyai pengaruh terhadap kondisi fisik. Sesuai dengan penjelasan Giriwijoyo (2010:22) bahwa :
Kebugaran jasmani adalah keadaan kemampuan jasmani yang dapat menyesuaikan fungsi alatalat tubuhnya terhadap tugas gerak tertentu dan/atau terhadap keadaan lingkungan yang harus diatasi dengan cara yang efisien, tanpa kelelahan yang berlebihan dan telah pulih sempurna sebelum dating tugas yang sama pada esok harinya.

Oleh karena itu diperlukan pembinaan dan pemeliharaan kebugaran jasmani siswa secara berkelanjutan yang berefek kepada tingkat kebugaran jasmani yang baik sehingga terbentuk selfesteem yang tinggi. Kegiatan ekstrakurikuler merupakan kegiatan yang memperluas dan memperdalam hubungan mata pelajaran, menyalurkan bakat dan minat dan dilakukan dalam waktu diluar jam pembelajaran. Ekstrakurikuler disekolah dibagi menjadi dua, yaitu : ekstrakurikuler olahraga dan ekstrakurikuler non olahraga yang masing-masing mempunyai perbedaan dalam pembentukan nilai-nilai karakter khususnya self-esteem. 


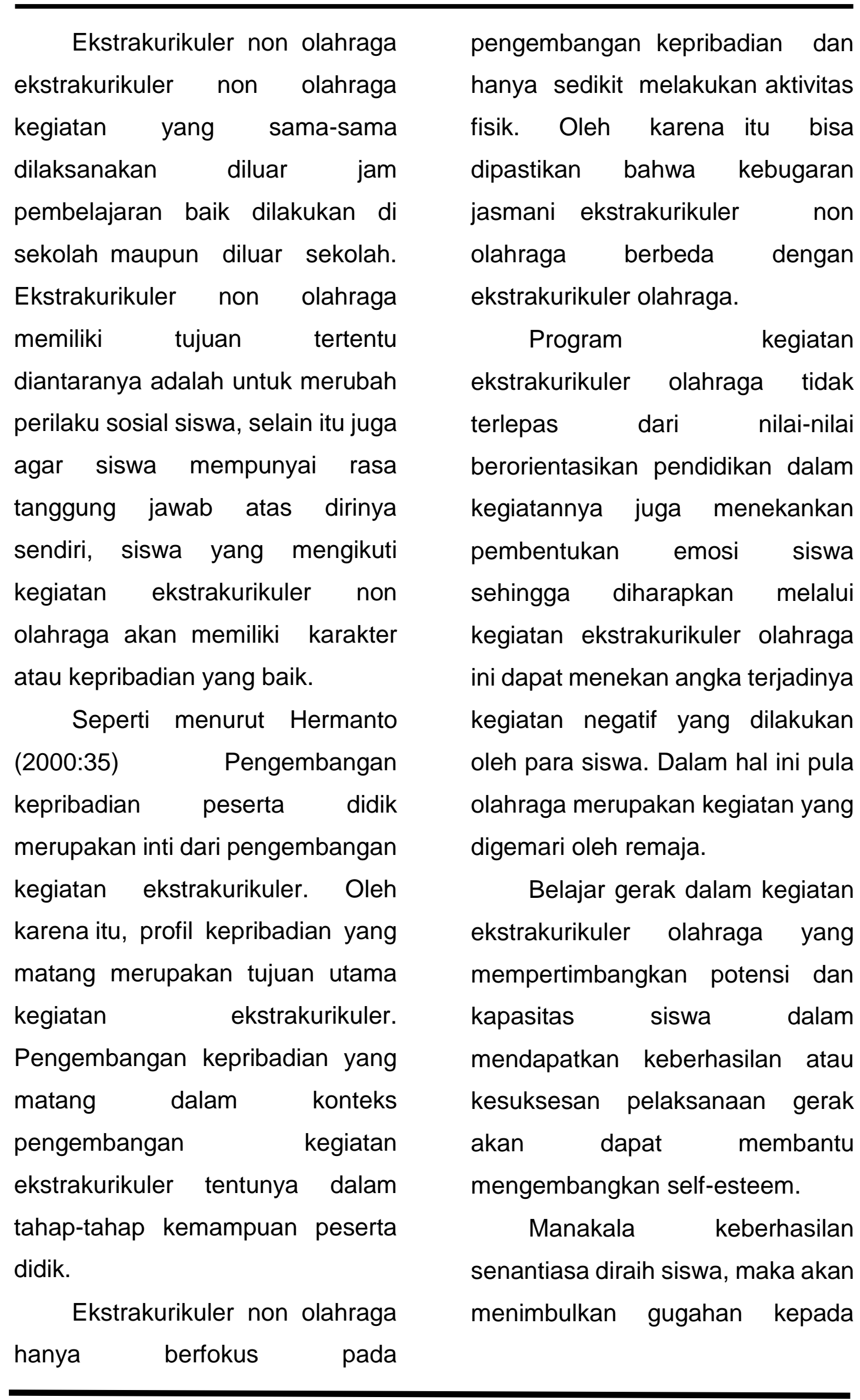


siswa tersebut untuk senantiasa terus terlibat dalam kegiatan aktivitas jasmani. Sesuai dengan penjelasan

Budimansyah

(2011:115) menjelaskan bahwa

"Olahraga berkenaan dengan proses persepsi, kesiapan, peniruan, manipulasi dan penciptaan aktivitas baru disertai sportivitas menghasilkan karakter tangguh".

\section{Naishmith}

menjelaskan bahwa, 'Physical activity provides challenges to the body. These are opportunities for feeling succesfull and competent. Achieving short and long term goals related to these challenges promote feelings of competences.' Aktivitas gerak menyediakan tantangan pada tubuh.

Pada kesempatan ini akan merasakan kesuksesan dan berkompetensi dalam melakukannya. Meraih tujuan yang pendek maupun panjang berhubungan dengan tantangan untuk meningkatkan kompetensi. Sesuai dengan hasil pembahasan di atas maka kebugaran jasmani siswa yang mengikuti program ekstrakurikuler olahraga lebih baik dari kegiatan ekstrakurikuler non olahraga dalam pembentukan selfesteem.

Diketahui nilai t-hitung untuk kebugaran jasmani adalah 2.126 dengan probabilitas Sig. (2tailed) 0,038 . Karena probabilitas (Sig.) $0,038<0,05$ maka $\mathrm{HO}$ Ditolak. Artinya Kebugaran jasmani siswa yang mengikuti Ekstrakurikuler Olahraga lebih baik daripada siswa yang mengikuti Ekstrakurikuler Non Olahraga.

3. Ekstrakurikuler dan kebugaran jasmani secara simultan berpengaruh terhadap selfesteem siswa.

ANCOVA merupakan teknik analisis yang berguna untuk meningkatkan presisi sebuah percobaan karena didalamnya dilakukan pengaturan terhadap peubah bebas lain yang tidak terkontrol. ANCOVA digunakan jika peubah bebasnya mencakup variabel kuantitatif dan kualitatif. Selanjutnya dilakukan pengujian untuk mengetahui pengaruh ekstrakurikuler terhadap pembentukan self- esteem siswa. 
Pengujian ini dilakukan dengan menghilangkan pengaruh kebugaran jasmani dari model. Dari hasil pengolahan terlihat bahwa angka signifikansi untuk peubah ekstrakurikuler adalah 0,000. Karena nilainya jauh di bawah 0,05 maka Ho ditolak. Sehingga dapat disimpulkan bahwa tanpa pengaruh kebugaran jasmani, pada tingkat kepercayaan 95\% ada pengaruh perbedaan ekstrakurikuler terhadap pembentukan self-esteem siswa.

Untuk mengetahui pengaruh kebugaran jasmani dan perbedaan ekstrakurikuler terhadap nilai yang diperoleh siswa secara simultan dapat dilihat dari angka signifikansi pada Corrected Model. Terlihat bahwa angka signifikansinya adalah sebesar 0,000. Karena nilai signifikansi jauh di bawah 0,05 maka Ho ditolak. Sehingga pada tingkat kepercayaan $\quad 95 \%$ dapat disimpulkan bahwa secara ekstrakurikuler dan kebugaran jasmani simultan berpengaruh terhadap pembentukan selfesteem.

\section{E. Kesimpulan}

Kegiatan ekstrakurikuler merupakan kegiatan diluar jam pembelajaran yang berkaitan dengan program kokurikuler dan intrakurikuler. Kegiatan ini dapat dijadikan sebagai wadah bagi siswa yang memiliki minat mengikuti kegiatan tersebut. Melalui bimbingan dan pelatihan guru, kegiatan ekstrakurikuler dapat membentuk sikap positif terhadap kegiatan yang diikuti oleh para siswa. Kegiatan ekstrakurikuler yang diikuti dan dilaksanakan oleh siswa baik di sekolah maupun diluar sekolah, bertujuan agar siswa dapat memperkaya dan memperluas diri. Sesuai dengan penjelasan Rusli Lutan (1986:72) menyatakan bahwa "Ekstrakurikuler merupakan bagian integral dari proses belajar yang menekankan pada pemenuhan kebutuhan anak didik".

Ekstrakurikuler secara garis besar dibagi menjadi dua, yaitu : ekstrakurikuler olahraga dan ekstrakurikuler non olahraga. Dalam hal ini kegiatan ekstrakurikuler sama-sama bertujuan dalam memperluas dan 
mengembangkan pengetahuan dan mengembangkat bakat dan minat para siswa dalam pembentukan karakter siswa salah satunya self-esteem. Ice Hockey Federation (IIHF) (2010:2) menyatakan bahwa : "The there main processes which influence the development of one's self-esteem are social acceptance, social reinforcement, and social comparison."

Tiga proses utama yang mempengaruhi perkembangan self-esteem seseorang adalah penerimaan sosial, penguatan sosial, dan perbandingan sosial. Salah satu hal yang mungkin menjadi penyebab terjadinya keadaan ini adalah kurangnya tantangan dan pengakuan sosial.

Kebugaran jasmani mempunyai fungsi yang sangat penting bagi kehidupan seseorang dalam melakukan kegiatan seharihari. Kebugaran jasmani berfungsi untuk meningkatkan kemampuan kerja bagi siapapun yang memilikinya sehingga dapat melaksanakan tugas-tugasnya secara optimal untuk mendapatkan hasil yang lebih baik.
Untuk peningkatan dan pemeliharaan kebugaran jasmani tidak terlepas dari aktfitas fisik yang membina keseimbangan unsur kesegaran jasmani. Untuk membina atau memelihara kesegaran jasmani, salah satu caranya adalah dengan melakukan latihan fisik atau latihan jasmani salah satunya adalah mengikuti kegiatan ekstrakurikuler. Sehingga dapat disimpulkan bahwa ekstrakurikuler dan kebugaran jasmani secara simultan berpengaruh terhadap self-esteem siswa.

Berdasarkan hasil pembahasan pada penelitian ini dapat disimpulkan bahwa Selfesteem siswa yang mengikuti program ekstrakurikuler olahraga lebih baik daripada ekstrakurikuler non olahraga. Tidak ada pengaruh perbedaan kebugaran jasmani terhadap self-esteem siswa yang mengikuti ekstrakurikuler. Kegiatan ekstrakurikuler dan kebugaran jasmani secara simultan berpengaruh terhadap self-esteem siswa.. 


\section{DAFTAR PUSTAKA}

Fraenkel, JR, Wallen, NE. (1993).

How To Design and Evaluate

Research in Education. USA;

McGraw Hill, Inc.

Nisfiannoor, M. (2009). Pendekatan

Statistik Modern untuk IImu social. Jakarta: Salemba Humanik

Rusli, Lutan . (2003a). Self esteem; landasan kepribadian, Jakarta; Bagian Proyek

Peningkatan Mutu Organisasi dan Tenaga Keolahragaan Dirjen Olahraga Depdiknas.

Rusli, Lutan (1986). Pengelolaan Interaksi Belajar Mengajar Intrakulikuler, kokulikuler, dan ektrakulikuler. Jakarta : Departemen Pendidikan dan Kebudayaan Universitas Terbuka

Mulyana. (2013). Pendidikan pencak silat membangun jati diri bangsa. Bandung: Remaja Rosdakarya

Tarigan, B. (2009). Optimalisasi

Pendidikan Jasmani dan Olahraga Berdasarkan

IImu Faal Olahraga. Bandung: FPOK UPI
Budimansyah,

D.

(2011).

Pembinaan

Karakter

Generasi Muda. Bandung :

CV Dua Usaha Utama

Coopersmith,S. (1967). The

Antecedents of Self-Esteem.

San Francisco: W.H. Freeman and Company.

Kerlinger, F.M. (1964). Fondation of

Behavioral

Research.

NewYork: Holt, Rinehart, \& Winston.

Koeswara, (1991). Teori-Teori

Kepribadian. Bandung: PT

Gresco

Nurhasan. dan Hasanudin (2007).

Tes dan Pengukuran

Keolahragaan. Bandung : FPOK UPI

Bridges, Kaci A. et al. (2007).

"Physical Activity, Exercise, and Physical Fitness:

Definitions and Distinctions for Health-Related Research". Californian Journal of Health Promotion. USA.

Rosdiani, Dini. (2012) Dinamika Olahraga dan Pengembangan Nilai, Bandung : Alfabeta 
Sugiyono. (1999). Metode

Penelitian

Administrasi.

Bandung: Alfabetha.

(2009). Metode Penelitian

Pendidikan Pendekatan

Kuantitatif, Kualitatif dan R \&

D. Bandung: Alfabetha.

(2010). Metode Penelitian

Pendidikan Pendekatan

Kuantitatif, Kualitatif dan R \&

D. Bandung: Alfabetha.

Giriwijoyo, Santosa. (2010). IImu

Faal Olahraga. Bandung :

Diktat FPOK IKIP Bandung.

Jurnal :

Andriani 'et al' (2010). Paparan

Media Dan Tindakan

Kekerasan Anak Jalanan

Media Exposure And Street

Children Violence. FKM

Unhas.

Deviandri, M. (2012). Dampak game online bagi perilaku siswa sekolah dasar di kelurahan gunung pengilun kecamatan padang utara kota padang. STKIP Padang

International Ice hockey federation (IIHF). (2010, Januari). Building Self-Esteem Level II. [Online].
Naismith, James. (1995). Physical Activity Promotes SelfEsteem. [Online].Tersedia : http://www.ncbi.nlm.nih.gov/p mc/articles/PMC1487216/[20 september 2011]

Narmoatmojo, Winarno (2009). Ekstrakurikuler di Sekolah : Dasar Kebijakan dan Aktualisasinya. [Online]. Tersedia

http://winarno.staff.fkip.uns.ac .id/files/2009/10/Makalah-

Ekskul-di-Sekolah.pdf [14 Mei 2011]

Dokumen resmi :

Departemen Pendidikan dan Kebudayaan. (1995).

Petunjuk Tekniks Kegiatan Ektrakulikuler. Jawa Barat : Departemen Pendidikan dan Kebudayaan.

Depdikbud. (1992). Surat Keputusan (SK) Direktur Jenderal Pendidikan dasar dan Menengah (Dirjen Dikdasmen) Nomor: 226/C/Kep/0/1992. Jakarta : Depdikbud 
Didaktik : Jurnal Pendidikan Guru Sekolah Dasar, ISSN : 24775673

Sekolah Tinggi Keguruan dan IImu Pendidikan Subang Volume III Nomor 1, Desember 2017 